\title{
Potential of Grey Water Recycling in Water Scarce Urban Areas in Bangladesh
}

\author{
M. Dakua, M. Mahmood, S. Bhowmik, and F. Khaled
}

\begin{abstract}
Constructed wetland, being simple inconstruction and maintenance and operation, is a biological process which intends to interact among media, plants, waste water and microorganisms for a better treatment of grey water from households. The objectives of this study were to perform quantitative analysis of grey water recycling using constructed wetland process (horizontal and vertical flow) and feasibility study of application of recycled water in daily use. It included a residential staff quarter, a residential hostel and a hospital as the subject area. The three different types of water consumption rate in different sectors in these areas and the amount of produced and recycled grey water were studied. The findings are, recycled grey water can be successfully used in several daily use purposes and the production of recycled water is much higher than demand. With the use of recycled water, it can be saved $17.62 \%, 19.22 \%$ and $17.71 \%$ of total water of the three respective subject areas. Reduction of water bill to some extent and betterment of environment by improving the quality of downstream waste water and reduction in groundwater depletion by less withdrawal of water is also possible.
\end{abstract}

Index Terms-Constructed wetlands, reusable water, water consumption, water scarcity.

\section{INTRODUCTION}

Urbanization in Bangladesh is causing increasing demand for water in urban areas. Though Bangladesh is a riverine country, majority of the urban population uses groundwater for daily use. As a result of huge consumption, on the contrary, poor recharge, ground water level is depleting $3 \mathrm{~m}$ every year [1]. Thus, new water sources have to be developed, e.g. exploitation of more distant (surface water) and deeper (groundwater) sources, construction of new dams, and desalination. Not only that the cost of utilizing these "new" sources is expected to be higher than the cost of "conventional" water sources, but it is expected to cause increasing negative environmental effects. Hence recycling of grey water can be a promising solution to water crisis and can be used as an alternative resource. Amongst the processes of recycling, constructed wetland (horizontal and vertical flow) process is now being popular for its certainty, low cost and ecofriendly setup. The wetland function related to hydrology and water quality includes supply of treated water suitable to be reused in several applications, increase of surface water quality, and recharge of aquifers and reduction in water bills.

In one of the most widely accepted definitions, constructed wetlands are "man-made complexes of saturated substrate, emergent and submerged vegetation, animal life and water

Manuscript received July 22, 2015; revised September 17, 2015.

The authors are with Bangladesh University of Engineering and Technology, Bangladesh (e-mail:mukseet.mahmood@gmail.com). that simulate natural wetlands for human use and benefits" [2]. The basic mechanism of organic matter degradation in constructed wetlands is Plant bacterial symbiotic reactions, in which gaseous oxygen photo synthetically produced or taken up for respiration by the plant is used by aerobic and facultative bacteria [3]. The application of constructed wetlands for treatment of municipal wastewater is constantly increasing due to good treatment performances and low construction and operating costs [4]. CWs for wastewater treatment may be classified according to the life form of the dominating macrophyte, into systems with free-floating, floating leaved, rooted emergent and submerged macrophytes [5]. Further division could be made according to the wetland hydrology (free water surface and subsurface systems) and subsurface flow CWs could be classified according to the flow direction (horizontal and vertical) [6]. As polishing step of conventionally engineered wastewater treatment plants, constructed wetlands seem to represent an effective, technologically simple and economically affordable solution to the increasing pressure on surface waters. Their high quality effluents can be suitable for reuse in various forms also.

In Bangladesh, still recycled water usage is not popular. But prior to the problems addressed, recycling and using grey water can be a very helpful tool in reduction of water consumption from natural sources and saving the environment as the present state of water level is posing a serious threat towards the future and we are the one to pay the toll. In this paper, the economic and environmental benefits of constructed wetland process of recycling of grey water in households are discussed. This paper is mainly intended to discuss on the quantitative analysis of this recycling. Findings of this paper would provide some information based on which future interventions can be planned to better deal with water scarcity issues in these areas.

\section{LITERATURE REVIEW}

Domestic in-house specific water demand in industrialized countries approximates 100-150 1/c/d (liter/capita/day), of which $60-70 \%$ is transformed into grey water, while most of the rest is consumed for toilet flushing and released as black water [7]. Another study shows that, grey water from bathroom sinks, tubs, showers kitchen sinks and dishwashers, include 50-80\% of household wastewater [8]. A typical VF system can remove the BOD5 up to $96 \%$; the HF system can remove only up to $65 \%$ [9]. Grey water reuse for toilet flushing can reduce the in-house net water consumption leading to $10-20 \%$ reduction of the urban water consumption, which is significant especially under water scarcity situation 
[8]. Adding with this, recycled grey water can be used in irrigation, watering golf course, and gardening, cleaning, and washing and in ground water recharge. For example, Friedler and Galil [10] showed that in the year 2023 with a moderate penetration ratio of grey water reuse systems of $20-30 \%$ (percentage of houses having grey water reuse units installed), reuse of grey water in the urban sector in Israel (projected population $10 * 106$ people) could save 30-55 MCM y-1 (million cubic meters/year) - 25-45 and 5-10 MCM y-1 in toilet flushing and garden irrigation respectively. This amounts to about $5 \%$ of the total future urban water demand in the country, and equals the capacity of a medium size seawater desalination plant in Nepal, existing wetland treatment plants are treating grey water per day in following amount - Dhulikhel Hospital $40 \mathrm{~m} 3$, Private house at Dallu $0.5 \mathrm{~m} 3$, Staff Quarter of Middle Marshyangdi Hydro Electric Power Station 26m3 [9]. Wetland process is being implied with success in Nepal, EU, Japan, USA and Australia. [9], [11]-[16].

Supply of reusable water Constructed wetlands is already in use in much wastewater reclamation and reuse schemes worldwide [17]. Domestic grey water was found to contribute as much as $55-70 \%$ of the specific daily load of TSS and $\mathrm{BOD}_{5}$ in municipal sewage. Typically, grey water from bathroom sinks, tubs, showers kitchen sinks and dishwashers, include $50-80 \%$ of household wastewater [8]. Domestic in-house specific water demand in industrialized countries approximates 100-150 1/c/d (litre/capita/day), of which $60-70 \%$ is transformed into grey water [7]. The kitchen sink was signaled out as a major contributor of VSS, COD, and BOD with $58 \%, 42 \%$ and $48 \%$, of their total daily load respectively. The washing machine was established as a significant contributor of sodium, phosphate and COD (40\%, $37 \%$ and $22 \%$ of the total load). The dishwasher, although contributing only $5 \%$ of the flow, was found to be a significant contributor of phosphate and boron [7]. Juwarker et al. [18] found 78 to $90 \%$ organic matter removal in a reed bed. Gersberg et al. [19] reported nitrogen removal to the extent of 28 to $91 \%$ in the constructed wetland. Ammonia- nitrogen and total nitrogen removal efficiency in the reed beds of Kathmandu University (KU) were found to be 86 and $58 \%$ respectively. Similarly, in the wetland of Dhulikhel Hospital (DH) in Nepal, ammonia- nitrogen and total nitrogen removal efficiency were observed to be 61 and $33 \%$ respectively. Removal of faecal coli form was $98 \%$ and total suspended solid (TSS) removal was excellent in the both wetlands. Orthophosphate-phosphorous concentration in the outlet of $\mathrm{KU}$ was reduced from 8 to $2 \mathrm{mg} / \mathrm{L}$. The mean organic matter removal efficiency in wetlands of $\mathrm{DH}$ and $\mathrm{KU}$ was observed to be 85 and $93 \%$ respectively [20].

The polishing step of treatment provided by constructed wetlands can make the treated wastewater suitable for recharging the aquifers in areas of over-exploitation of groundwater resources and thus provide a beneficial effect in the water resources management. It must be observed that the groundwater recharge does not occur in the location of the constructed wetland itself since the permeability of the wetland bottom is typically very low to avoid infiltration of polluted wastewater into the soil. The effluent can also improve the quality of water surface body. Constructed wetlands provide a tool to reanimate the "dead" treated wastewater and transform it into usable natural surface water. This aspect of the treatment with constructed wetland has been extensively studied in the "Waterharmonica" project in the Netherlands [21]. The key point of the "Waterharmonica" concept is that free water surface constructed wetlands not only provide a significant reduction of key contaminants (like chemical oxygen demand, pathogens, nutrients etc.) but their effluent is much more similar to a natural healthy surface water than the effluent of a conventional mechanical treatment plant.

\section{Methodology}

In this paper, applicability and potential of using recycled grey water in domestic use was studied for a hospital, a hostel and a residential area. These three types of places were selected because of their different types of water consumption rate. For recycling, constructed wetland process (horizontal and vertical flow) was considered. Water used daily in cooking, cleaning, washing clothes and in dining, bathing, flushing and gardening in these 3 places was calculated. It was estimated from the literature that after recycling, 70\% grey water remains usable and it was considered that this recycled water could be used in cleaning, washing, gardening and flushing. Data was collected to check if required recycled water in these 4 sectors meets availability. Monthly water bills of hospital, hostel and residential building was checked to compare probable changes in billing after using recycled water. Environmental cost study was also carried out to establish recycled water as a potential remedy of water scarcity. For hospital survey, Ayesha Memorial Hospital; for residential survey, BUET staff quarter and for hostel survey, Titumir hall of BUET was considered. In this research, the water consumption of these places was observed by surveying. After this observation, it was calculated if the recycled water can meet up these four sectors water demand. In this paper, the daily water consumption of these places was shown with some tables and pie charts. In addition, a comparison between the recycled water and the water demand of these 4 sectors were also shown with a bar chart for each place. This paper also shed some lights on the future use of the retained recycled water that might reduce impact of groundwater extraction and surface water pollution, hence protecting environment against future worse condition.

\section{RESUlT AND DISCUSSION}

A survey was conducted to estimate the total daily water use of the habitants of a hostel (Table I), a hospital (Table II) and a residential area (Table III). From our data collection we found that there are 464 allotted students and 26 staffs residing in Titumir Hall of BUET and in staff quarter of BUET there are 19 buildings each having 19 families residing there. Along with that we were informed that Ayesha Memorial Hospital can accommodate approximately 300 patients at a time. Fig. 1 shows the variety of water use in different sectors. In this survey, it was observed that water consumption is significantly high for bathing purpose and 
other personal use. Personal use involves water use for freshening up, performing ablution, drinking etc. Water is being used in some sectors where the quality parameters are not strictly maintained. Such as flushing toilets and urinals, gardening, cleaning of floors, washing clothes etc. Recycled grey water can be used in these sectors. The daily approximate amount of used water in Ayesha memorial hospital, Staff quarter of BUET and Titumir hall of BUET are provided here

TABLE I: DAILY WATER USE IN TITUMIR HALI

\begin{tabular}{|l|l|}
\hline Sector of water use in Titumir & Amount of water (liters) \\
\hline Hall & \\
\hline Bathing and personal use & 44100 \\
\hline Cooking & 2500 \\
\hline Washing (Dining) & 12250 \\
\hline Flushing & 7350 \\
\hline Gardening & 250 \\
\hline Cleaning floors & 1500 \\
\hline Washing clothes & 4900 \\
\hline Total use & 72850 \\
\hline
\end{tabular}

TABLE II: DAILY WATER USE IN AYESHA MEMORIAL HOSPITAL

\begin{tabular}{|l|l|}
\hline Sector of water use in Hospital & Water amount (liters) \\
\hline Bathing and personal use & 54000 \\
\hline Cooking & 3500 \\
\hline Washing (Dining) & 15000 \\
\hline Flushing & 13500 \\
\hline Gardening & 0 \\
\hline Cleaning floors & 100 \\
\hline Washing clothes & 2000 \\
\hline Total use & 88100 \\
\hline
\end{tabular}

TABLE III: DAILY WATER USE IN STAFF QUARTER, BUET

\begin{tabular}{|l|l|}
\hline Sector of water use in Staff quarter & Water amount (liters) \\
\hline Bathing and personal use & 85500 \\
\hline Cooking & 5700 \\
\hline Washing (Dining) & 28500 \\
\hline Flushing & 14250 \\
\hline Gardening & 350 \\
\hline Cleaning floors & 1500 \\
\hline Washing clothes & 9500 \\
\hline Total use & 145300 \\
\hline
\end{tabular}

In this study, the amount of water used every day is approximately 145,300 liters in staff quarter of BUET, 88,100 liters in Ayesha memorial hospital and 72,850 liters in Titumir hall of BUET. The daily water requirement of all these places is significant enough. Besides bathing and personal use a large portion of water is used in flushing in toilets and washing in dining. A simple pie chart will represent the water consumption percentage in each sector in the above three type of facilities.

Under normal condition total water requirement is supposed to be met from the main supply sources of water in the city. In order to reduce the consumptive pressure on the main supply sources recycled grey water can be used in some sectors where strictly maintaining the water quality is not necessary though a minimum improvement is needed. From the literature, 70 percent of the used water in a household is grey water and it can be recycled easily by wetland. After the recycling it can be used in flushing in toilets, gardening, cleaning floors and washing clothes. If recycled grey water is used in these residences the total water needed for these daily activities are provide in Table IV, Table V and Table VI.

\section{Daily water use in Titumir hall}

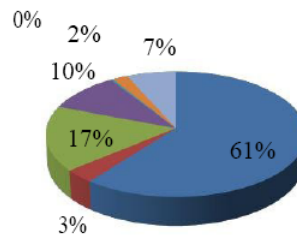

$$
\begin{aligned}
& \text { bathing and } \\
& \text { personal use } \\
& \text { cooking(dining) } \\
& \text { washing(dining) } \\
& \text { w flushing } \\
& \text { gardening } \\
& \text { w cleaning floors } \\
& \text { w washing clothes }
\end{aligned}
$$

a)

Daily use of water in Hospital

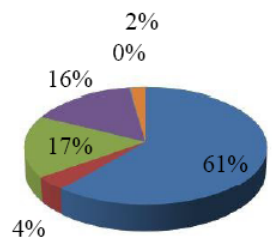

$$
\begin{aligned}
& \text { - bathing and } \\
& \text { personal use } \\
& \text { - cooking } \\
& \text { washing(dining } \\
& \text {-Flushing } \\
& \text {-Cleaning floors } \\
& \text { washing clothes }
\end{aligned}
$$

b)

Daily water use in a staff quarter
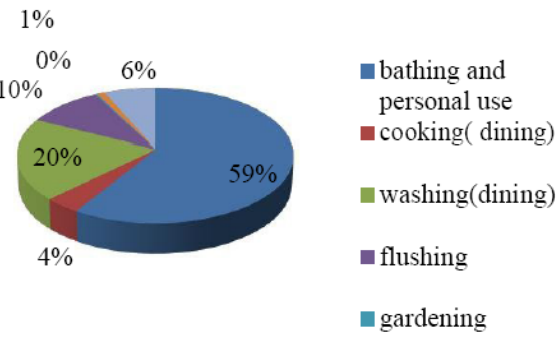

c)

Fig. 1. Daily water use in different sectors in percentage a) Titumir hall b) Ayesha memorial hospital c) Staff quarter.

TABLE IV: USE OF RECYCLED WATER IN TITUMIR HALL

\begin{tabular}{|l|l|}
\hline Sectors of recycled water & Water required (Liters) \\
\hline use in Titumir & \\
\hline hall & \\
\hline Flushing & 7350 \\
\hline Gardening & 250 \\
\hline Cleaning floors & 1500 \\
\hline Washing clothes & 4900 \\
\hline Total use & 14000 \\
\hline
\end{tabular}

TABLE V: USE OF RECYCLED WATER IN AYESHA MEMORIAL HOSPITAL

\begin{tabular}{|l|l|}
\hline Sectors of recycled water & Water required (Liters) \\
\hline use in Hospital & \\
\hline Flushing & 13500 \\
\hline Gardening & 0 \\
\hline Cleaning floors & 100 \\
\hline Washing clothes & 2000 \\
\hline Total use & 15600 \\
\hline
\end{tabular}


TABLE VI: USE OF RECYCLED WATER IN STAFF QUARTER

\begin{tabular}{|l|l|}
\hline Sectors of recycled water use in staff quarter & Water \\
\hline & Required \\
\hline Flushing & (Liters) \\
\hline Gardening & 14250 \\
\hline Cleaning floors & 350 \\
\hline Washing clothes & 1500 \\
\hline Total use & 9500 \\
\hline
\end{tabular}

In this research, it was also found that the recycled grey water is enough for these purposes to use (Fig. 2). In Titumir hall 50,995 liters water would be available per day and the demand of water for these four purposes is 14,000 liters. So, about 36,995 more liters of water will be available after using. Additionally, in the staff quarter in BUET the total recycled water will be available 101,710 liters per day and water required for these 4 operations is 25,600 liters. Almost 76110 more liters of water is available after using. Moreover, in Ayesha memorial hospital the total recycled grey water amount will be 61,670 liters and the amount required for these 4 purposes is 15,600 liters. About 46,070 more liters of water are available after using.

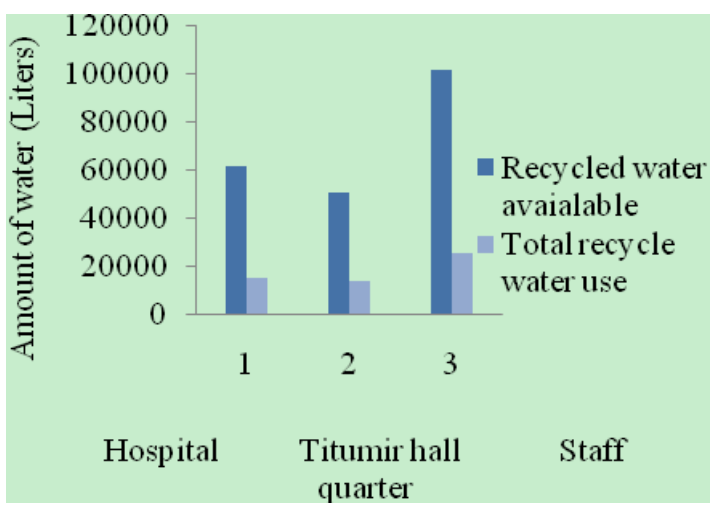

Fig. 2. Bar charts of total recycled water use and recycled water available.

In addition, by recycling and reusing the water, the water cost will have a reduction. In these three buildings recycled water can be used in various sectors. In this study, it is seen that about 14000 liters in Titumir hall, 15600 liters in Ayesha memorial hospital and 25600 liters in staff quarter can be used after recycling in flushing, gardening, cleaning rooms and washing clothes. DWASA charges 5.5 tk per 1000 liters for domestic use and 18.25 tk for commercial and industrial use. So a reduction in water bill will be come off by using this recycled grey water.

It has been also found in this research that a minimum amount of ground water can be saved daily by using this recycled water. About 14,000 liters of water in titumir hall, 15,600 liters of water in Ayesha memorial hospital and 25,600 liters of water in the staff quarter can be saved from the ground water regularly by the recycling which is about 19.22 percent of the total water consumed in titumir hall, about 17.71 percent of the total water consumed in Ayesha memorial hospital and about 17.62 percent of the total water consumed in the staff quarter. This water can be used for various activities in these places. This water recycling system can also lessen the water bills as well as lessen the pressure to the ground water consumption.

If the recycled grey water is used in these sectors, water consumption from main supply sources will definitely reduce which will lessen the rate of ground water depletion by reducing withdrawal for those surplus supplies. Moreover, if the available recycled water can be used to recharge the ground water, the ground water table will lower by a slow rate than before. During extreme events, conventional mechanical treatment plants may fail to achieve the treatment goals or may bypass part of the influent to the outlet after primary treatment only. Under these circumstances the wetland basin can contain the failures and provide treatment of the wastewater prior to the discharge into the receiving surface water body. Thus this process can make a better quality effluent in the downstream. Thus, the quality of discharge moving into the river will improve to a considerable level. The better downstream water quality will improve the health of the river body and also helpful for the fish habitat.

\section{CONCLUSION}

According to our study, applicability of using recycled water in daily use brings benefit to a great extent both for environment and for consumers. This study has found that with the use of recycled water, it can be saved $19.22 \%$ of total water in Titumir hall, $17.71 \%$ of total water in hospital and $17.62 \%$ of total water in staff quarter easily which is used in cleaning, washing, gardening and flushing and availability of recycled water is more than enough for the sectors in which it can be used. The available recycled water as well as the effluent can also be thrown to the nearby water body and improve the health of the water body. As water scarcity is a potential threat for upcoming decades, increasing usage of recycled water can be a savior.

\section{REFERENCES}

[1] S. Luby, "Water management for a healthy Bangladesh: The need for multi-sector collaboration," presented at National Public Health Conference, 2013.

[2] D. A. Hammer and R. K. Bastian, "Wetlands ecosystems: natural water purifiers?" in "Constructed wetlands for wastewater treatment," pp. 5-21, 1989.

[3] C. Polprasert, N. R. Khatiwada, and J. Bhurtel, "A design model for COD removal in constructed wetlands based on biofilm activity," $J$. Env. Engg., Div., vol. 124, no. 9, pp. 838-843, 1998.

[4] R. H. Kadlec, R. L. Knight, J. Vymazal, H. Brix, P. Cooper, and R Haberl, "Constructed wetlands for pollution control. Process, performance, design and operation," IWA Scientific and Technical Report, No. 8, 2000.

[5] H. Brix and H. Schierup, "The use of macrophytes in water pollution control," Wastewater Treatment in Constructed Wetlands with Horizontal Sub-Surface Flow, Springer: Dordrecht, The Netherlands, 2008.

[6] J. Vymazal and L. Kröpfelová, Wastewater Treatment in Constructed Wetlands with Horizontal Sub-surface Flow, Springer: Dordrecht, The Netherlands, 2008

[7] E. Friedler, "Quality of individual domestic greywater streams and its implication for on-site treatment and reuse possibilities," June 2004.

[8] S. Thakur and M. S. Chauhan, "Grey water recycling," 2013.

[9] K. L. Shrestha, "Decentralised wastewater management using constructed wetlands in Nepal," December 2008.

[10] E. Friedler and N. I. Galil, "On-site greywater reuse in multi-storey buildings: Sustainable solution for water saving," presented at Int. Conf. on Efficient Use and Management of Urban Water, April 2003.

[11] E. A. Gardner, "Some examples of water recycling in Australian urban environments: a step towards environmental sustainability," Water Sci. Technol., vol. 3, pp. 21-23, 2003. 
[12] E. Nolde, "Greywater reuse systems for toilet flushing in multi-storey buildings: Over ten years' experience in Berlin," Urban Water, vol. 1, pp. 275-284, 1999.

[13] V. Lazarova, S. Hills, and R. Birks, "Using recycled water for non-potable, urban uses: A review with particular reference to toilet flushing," Water Sci. Technol., vol. 3, pp. 69-77, 2003.

[14] M. Ogoshi, Y. Suzuki, and T. Asano, "Water reuse in Japan," Water Sci. Technol., vol. 43, pp. 17-23, 2001

[15] A Study of Domestic Greywater Recycling. Environment Agency, UK, 2000.

[16] A. D. Wheatley and S. Surendran, "The design and operation of a grey water treatment plant," Effectiveness of Water Conservation Options, pp. 535-544, 2003.

[17] D. Bixio et al., 4th IWA World Congress, September 19-24, 2004 , Marrakech, Morocco, 2004.

[18] A. S. Juwarker, B. Oke, and S. M. Patnaik, "Domestic Wastewater Treatment through Constructed Wetland in India," Wat. Sc.Tech., vol. 12, no. 3, pp. 291-294, 1995.

[19] R. M. Gersberg, B. V. Elkin, S. R. Lyen, and C. R. Goldman, "Role of aquatic plants in wastewater treatment by artificial wetlands," Wat. Res., vol. 20, pp. 363-398, 1986.

[20] K R Bista and N R Khatiwada, "Performance study on reed bed wastewater treatment units in Nepal," 2010.

[21] T. Claassen and R. Kampf, "Environmental impact of polishing with wetland systems; the water harmonica experience," presented at Implementation and Operation of Municipal Wastewater Reuse Plants, Thessaloniki, Greece, 2004.

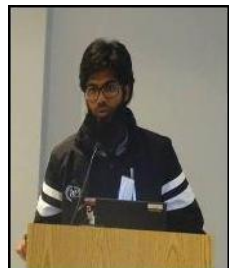

M. Dakua was born on December 13, 1985. He completed his B.Sc. in civil engineering in 2009 from Bangladesh University of Engineering and Technology (BUET), Dhaka, Bangladesh and his M. Sc. in civil and environmental engineering in 2015 from BUET.

He is currently working as the project coordinator at International Training Network Center (ITN-BUET),

Dhaka. He was a state department fellow, Mobile Bay National Estuary Program, Mobile, Alabama, USA, from August 8, 2014 to November 30, 2014. He previously worked as a project coordinator in the project titled "Alternative options for access to safe water in coastal areas". He also worked as a consultant, Development of Water Safety Plan for 5 municipalities, Department of Public Health Engineering, funded by WHO, (March 2015 - ongoing). Some of his publications are "Potential of rainwater harvesting in buildings to reduce over extraction of groundwater in urban areas of Bangladesh", European Scientific Journal, etc. He is also a US state department alumnus, joint secretary of Rain Forum society.

Mr. Dakua was selected for participation in the Community Solutions Program, a program of the Bureau of Educational and Cultural Affairs (ECA) of the United States Department of State implemented by IREX (International Research and Exchanges Board), 2014-2015 and achieved 5.5 Continuing Education Units for Participation in IREX's Community
Leadership Institute (August 4-December 4, 2014); Office of Continuing Professional Education, George Mason University, Washington, DC, USA.

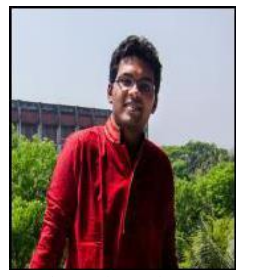

M. Mahmood was born in Rajshahi, Bangladesh on February 5, 1994. He pursued his studies in Bangladesh. He passed SSC (secondary school certificate) exam in 2008 from Govt. Laboratory High School, Rajshahi with science background. Then he passed HSC (higher secondary school certificate) exam in 2010 from New Govt. Degree College with science background. He is currently studying civil engineering in Bangladesh University of Engineering and Technology (BUET), Dhaka.

He is carrying out his research works mainly on low cost water treatment, salinity problems in coastal areas and analysis of shear walls in different methods. One of his publications was published in an international conference on "Climate change in relation to water and environment" etc.

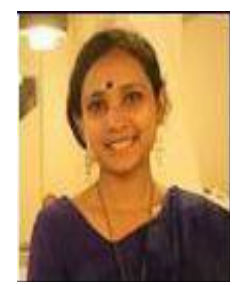

S. Bhowmik was born in Chittagong, Bangladesh on Dec. 12, 1993. She has completed S.S.C in science from Dr. Khastagir Govt. Girls' High School, Chittagong in 2008 and H.S.C in science from Ispahani Public School and College, Chittagong in 2010.

She is currently an undergrad student of Bangladesh University of Engineering and Technology, Dhaka in Civil Engineering Department. Her current research interest is wetland, green technology, low cost water treatment.



F. Khaled was born in Dhaka, Bangladesh on January 11, 1993. He pursued his studies in Bangladesh. He passed SSC (secondary school certificate) exam in 2008 from Rajuk Uttara Model College, Dhaka with science background. Then he passed HSC (higher secondary school certificate) exam in 2010 from Notre Dame College, Dhaka with science background. He is currently studying civil engineering with structural engineering as majorin Bangladesh University of Engineering and Technology, Dhaka.

$\mathrm{He}$ is carrying out his research works mainly on low cost water treatment, salinity problems in coastal areas and analysis of shear walls in different methods. One of his publications was published in an international conference on "Climate Change in relation to Water and Environment"(I3CWE-2015), which took place within 09-11 April,2015 at Dhaka University of Engineering and Technology, Gazipur, under the title "Salinity intrusion in Sundarbans region: Identifying major causes and possible remedies by desalination techniques". Another paper of his is selected for publication under the title "Lateral deflection of shear-wall frame structure: A parametric study with component stiffness method and finiteelement method" in UKIERI Concrete Congress 2015. 